Intecoms: Journal of Information Technology and Computer Science

Volume 1 Nomor 2, Desember 2018

e-ISSN : 2614-1574

p-ISSN : 2621-3249

DOI : https://doi.org/10.31539/intecoms.v1i2.297

\title{
PERANCANGAN RENCANA STRATEGIS TEKNOLOGI INFORMASI DI PUSAT TEKNOLOGI INFORMASI DAN PANGKALAN DATA UIN SUSKA RIAU
}

\section{DESIGN OF STRATEGIC PLANNING INFORMATION TECHNOLOGY IN INFORMATION TECHNOLOGY CENTER AND DATA CENTER OF UIN SUSKA RIAU}

\author{
Febrizal Alfarasy Syam \\ Universitas Lancang Kuning \\ febrizal@unilak.ac.id
}

\begin{abstract}
To support the vision of UIN Suska Riau, a Technical Implementing Unit in the field of computer and information system in UIN Suska Riau was established called the Computer Center (PUSKOM). However, in 2013, the Computer Center (PUSKOM) of UIN Suska Riau changed its name to the Information Technology and Database Center (PTIPD). The Center for Information Technology and Data (PTIPD) of UIN Suska Riau is a part that manages the use of information technology in the environment of Susin Riau UIN. PTIPD provides internet network services with a current bandwidth capacity of 200 Mbps. PTIPD also conducts training in information technology for students and lecturers and develops information systems and applications according to the needs of the UIN Susuka Riau academic community. Development of information systems that are not planned systematically will result in organizations not having a scale of priority in IS / IT development projects and seemingly patchy. The Center for Information Technology and Database (PTIPD) requires an appropriate strategic planning IS / IT, because if the IS / IT is not right both goals and objectives, then the IS / IT will not be a competitive advantage for the Center for Information and Database Technology (PTIPD) ) UIN Suska Riau. The form of Information Systems Strategic Planning that will be discussed in this study is to use the Ward and Peppard model, with input in the form of an analysis of the internal business environment and an analysis of the internal IS / IT environment. The results of this analysis will define the draft draft of the SI / IT strategy plan for the Information Technology and Database Center (PTIPD) of UIN Suska Riau.
\end{abstract}

Keywords: IS / IT Strategic Planning, PTIPD, SI / IT Strategies, Ward and Peppard

\begin{abstract}
ABSTRAK
Untuk mendukung visi UIN Suska Riau, maka didirikanlah Unit Pelaksana Teknis bidang komputer dan sistem informasi UIN Suska Riau bernama Pusat Komputer (PUSKOM). Namun, pada tahun 2013, Pusat Komputer (PUSKOM) UIN Suska Riau berganti nama menjadi Pusat Teknologi Informasi dan Pangkalan Data (PTIPD). Pusat Teknologi Informasi dan Pangkalan Data (PTIPD) UIN Suska Riau merupakan bagian yang mengelola penggunaan teknologi informasi di lingkungan UIN Suska Riau. PTIPD menyediakan layanan jaringan internet dengan kapasitas bandwith saat ini sebesar $200 \mathrm{Mbps}$. PTIPD juga melakukan pelatihan di bidang teknologi informasi untuk mahasiswa dan dosen serta mengembangkan sistem informasi dan aplikasi sesuai kebutuhan civitas akademika UIN Susuka Riau. Pengembangan sistem informasi yang tidak terencana secara sistematis akan mengakibatkan organisasi tidak memiliki skala prioritas proyek pengembangan SI/TI dan terkesan tambal sulam. Pusat Teknologi Informasi dan Pangkalan Data (PTIPD) memerlukan perencanaan strategis SI/TI yang tepat, karena apabila SI/TI tidak tepat baik sasaran maupun tujuan, maka SI/TI tidak akan menjadi sebuah keunggulan yang kompetitif bagi Pusat Teknologi Informasi dan Pangkalan Data (PTIPD) UIN Suska Riau. Bentuk Perencanaan Strategis Sistem Informasi yang akan dibahas dalam kajian ini adalah menggunakan model Ward and Peppard, dengan masukan berupa analisis lingkungan bisnis internal dan analisis lingkungan SI/TI internal. Hasil dari analisis ini akan mendefinisikan draft perancangan rencana strategi SI/TI bagi Pusat Teknologi Informasi dan Pangkalan Data (PTIPD) UIN Suska Riau.
\end{abstract}

Kata Kunci : Perencanaan Strategis SI/TI, PTIPD, Strategi SI/TI, Ward and Peppard 


\section{PENDAHULUAN}

Untuk mendukung visi UIN Suska Riauyaitu menjadi lembaga pendidikan tinggi utama yang mengembangkan ajaran Islam, ilmu pengetahuan, teknologi, dan seni secara integral di kawasan Asia Tenggara, maka didirikanlah Unit Pelaksana Teknis bidang komputer dan sistem informasi UIN Sultan Syarif Kasim Riau bernama Pusat Komputer (PUSKOM) dengan menerapkan Teknologi Informasi (TI) di bidang pendidikan dan pengajaran, penelitian, dan pengabdian masyarakat. Namun,pada tahun 2013, Pusat Komputer (PUSKOM) UIN Suska Riau berganti nama menjadi Pusat Teknologi Informasi dan Pangkalan Data (PTIPD).

Sistem informasi (SI) adalah suatu keterkaitan antara manusia, prosedur dan penggunaan teknologi untuk mengumpulkan, mengolah, menyimpan, menyebarkan dan menyajikan informasi yang digunakan oleh satu atau beberapa proses bisnis dalam organisasi, Sedangkan teknologi informasi (TI) adalah konvergensi antara teknologi komputer dan teknologi komunikasi yang menyebabkan sistem informasi dapat dibangun dan berjalan sebagaimana mestinya (Laudon dan Laudon, 2000).

Pengembangan sistem informasi yang tidak terencana secara sistematis akan mengakibatkan organisasi tidak memiliki skala prioritas proyek pengembangan SI/TI dan terkesan tambal sulam. Cara seperti ini akan berdampak pada penurunan produktivitas organisasi. (Ward dan Peppard, 2002). Perencanaan strategis sistem dan teknologi informasi dibutuhkan untuk mempersiapkan Pusat Teknologi Informasi dan Pangkalan Data (PTIPD) UIN Suska Riau dalam merencanakan pemakaian teknologi dan sistem informasi untuk organisasinya. Perencanaan tersebut dibutuhkan sekali untuk efisiensi dan efektivitas aliran informasi yang ada dalam bagian-bagian divisi dalam internal Pusat Teknologi Informasi dan Pangkalan Data (PTIPD) UIN Suska Riau dan untuk menyesuaikan gerak langkah PTIPD dengan perkembangan teknologi informasi untuk memenuhi kebutuhan teknlogi informasi organisasi di masa yang akan datang.

Penelitian ini diteliti berdasarkan kajian-kajian sebelumnya yang telah diteliti seperti Noerlina (2008) meneliti tentang model perencanaan strategi sistem dan teknologi informasi pada bidang distributor, Widyaningsih (2012) juga merancang strategis sistem informasi pada perguruan tinggi, Indra dkk (2008) juga merancang strategis sistem informasi dan teknologi pada St. Ignatius Education Center Palembang dan pada Febby (2012) menulis skripsi tentang analisis perencanaan strategi sistem informasi pada STAI Al-Azhar Pekanbaru.

Penelitian ini bertujuan untuk menganalisa strategi bisnis, strategi sistem informasi dan teknologi informasi internal yang digunakan oleh Pusat Teknologi Informasi dan Pangkalan Data (PTIPD) Universitas Islam Negeri Sultan Syarif Kasim sertamembuat draft rencana strategis teknologi informasi sebagai pendukung Rencana Strategis Pusat Teknologi Informasi dan Pangkalan Data (PTIPD) Universitas Islam Negeri Sultan Syarif Kasim.

\section{METODE PENELITIAN}

Perencanaan strategis dibuat dengan menggunakan model Ward dan Peppard dan pembahasan analisa dibatasi hanya sampai IT Strategy berdasarkan analisa lingkungan internal organisasi. Metode analisa yang digunakan untuk pengolahan data yaitu analisis SWOT. Berikut gambar tahapan 
Model Strategis SI/TI Ward dan Peppard :

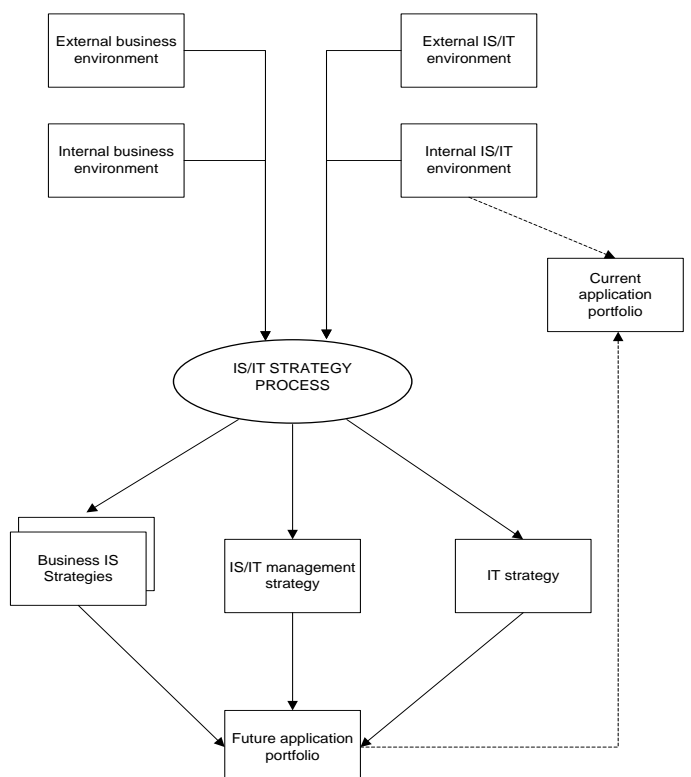

Gambar. 1 Model Strategis SI/TI Ward dan Peppard

\section{Tahap Analisa dan Perancangan Strategi TI}

Adapun kegiatan yang dilakukan dalam tahapan ini adalah sebagai berikut:

\section{Analisis SWOT}

Penulis menggunakan analisis SWOT (Strengths, Weaknesses, Opportunities, and Threats) disebut juga dengan analisis Kekepan (Kekuatan, kelemahan, peluang dan ancaman) digunakan untuk menilai kekuatan-kekuatan dan kelemahankelemahan dari sumber-sumber daya yang dimiliki perusahaan dan kesempatan-kesempatan eksternal dan tantangan-tantangan yang dihadapi.

\section{Analisis Strategi Bisnis}

\section{Analisis Lingkungan Bisnis Internal}

Analisis lingkungan bisnis internal digunakan untuk mengetahui strategi bisnis organisasi pada saat ini, visi, misi dan tujuan organisasi, aktivitas dan proses bisnis organisasi, sumberdaya yang dimiliki dan informasi yang dibutuhkan oleh organisasi.

\section{Analisis Strategi SI/TI \\ Analisis lingkungan SI/TI internal}

Analisis lingkungan SI/TI internal, yang mencakup kondisi SI/TI organisasi dari perspektif bisnis saat ini, bagaimana kematangannya (maturity), bagaimana kontribusi terhadap bisnis, keterampilan sumber daya manusia, sumber daya dan infrastruktur teknologi, termasuk juga bagaimana portofolio dari SI/TI yang ada saat ini.

\section{Perancangan IT Strategy}

IT Strategy, yang mencakup kebijakan dan strategi bagi pengelolaan teknologi dan sumber daya manusia SI/TI serta portofolio aplikasi SI/TI mendatang.

\section{HASIL DAN PEMBAHASAN \\ Analisa Kondisi Existing Pusat Teknologi Informasi dan Pangkalan Data (PTIPD)}

Sistem dan aplikasi teknologi informasi yang ada saat ini dapat dilihat pada tabel berikut ini :

Tabel. 1 Sistem dan Aplikasi TI

\begin{tabular}{|c|c|c|}
\hline NO & $\begin{array}{c}\text { Sistem dan } \\
\text { Aplikasi } \\
\end{array}$ & Kegunaan \\
\hline 1 & $\begin{array}{l}\text { Aplikasi } \\
\text { Billing } \\
\text { Internet }\end{array}$ & $\begin{array}{l}\text { Digunakan untuk } \\
\text { mengelola data } \\
\text { pengguna internet di } \\
\text { lingkungan kampus } \\
\text { meliputi hak akses } \\
\text { internet bagi dosen, } \\
\text { pegawai dan } \\
\text { mahasiswa }\end{array}$ \\
\hline 2 & $\begin{array}{l}\text { E-Learning } \\
\text { http://e- } \\
\text { learning.uin- } \\
\text { suska.ac.id }\end{array}$ & $\begin{array}{l}\text { Digunakan untuk } \\
\text { pembelajaran jarak } \\
\text { jauh. Sistem ini } \\
\text { menggunakan } \\
\text { aplikasi elektronik } \\
\text { untuk mendukung } \\
\text { belajar mengajar } \\
\text { dengan media } \\
\text { internet, jaringan } \\
\text { computer, maupun }\end{array}$ \\
\hline
\end{tabular}


computer standalone.

\begin{tabular}{|c|c|c|}
\hline 3 & Staff site & $\begin{array}{l}\text { Digunakan sebagai } \\
\text { media berbagi } \\
\text { informasi antar staf } \\
\text { PTIPD UIN Suska } \\
\text { Riau. }\end{array}$ \\
\hline 4 & $\begin{array}{l}\text { Web } \\
\text { Personal } \\
\text { Dosen }\end{array}$ & $\begin{array}{l}\text { Web ini digunakan } \\
\text { sebagai media } \\
\text { informasi antar dosen } \\
\text { di UIN Suska Riau. } \\
\text { Web ini dikelola oleh } \\
\text { PTIPD sebagai } \\
\text { bentuk tanggung } \\
\text { jawab pencapaian visi } \\
\text { PTIPD. }\end{array}$ \\
\hline 5 & $\begin{array}{l}\text { Blog } \\
\text { Mahasiswa }\end{array}$ & $\begin{array}{l}\text { Blog ini digunakan } \\
\text { sebagai media } \\
\text { bertukar informasi } \\
\text { antar mahasiswa UIN } \\
\text { Suska Riau. }\end{array}$ \\
\hline 6 & $\begin{array}{l}\text { Sistem } \\
\text { Pendaftaran } \\
\text { Online }\end{array}$ & $\begin{array}{l}\text { Sistem ini digunakan } \\
\text { sebagai tempat untuk } \\
\text { melakukan } \\
\text { pendaftaran } \\
\text { mahasiswa baru } \\
\text { melalui jalur mandiri } \\
\text { (UMJM) secara } \\
\text { online. }\end{array}$ \\
\hline 7 & $\begin{array}{l}\text { Sistem } \\
\text { Informasi } \\
\text { Kepegawaia } \\
\text { an }\end{array}$ & $\begin{array}{l}\text { Sistem ini berguna } \\
\text { untuk mengelola data } \\
\text { kepegawaiaan UIN } \\
\text { Suska Riau, antara } \\
\text { lain data pegawai, } \\
\text { kepangkatan dan } \\
\text { jabatan. }\end{array}$ \\
\hline 8 & $\begin{array}{l}\text { Sistem } \\
\text { informasi } \\
\text { UIN Suska } \\
\text { Riau }\end{array}$ & $\begin{array}{l}\text { Sistem ini berguna } \\
\text { sebagai media } \\
\text { penyimpanan } \\
\text { informasi mengenai } \\
\text { hal yang berkaitan } \\
\text { dengan kampus UIN } \\
\text { Suska. }\end{array}$ \\
\hline 9 & $\begin{array}{l}\text { SMS } \\
\text { Gateway } \\
\text { UIN Suska } \\
\text { Riau }\end{array}$ & $\begin{array}{l}\text { SMS digunakan } \\
\text { sebagai media untuk } \\
\text { penyampaian } \\
\text { informasi missal, } \\
\text { contoh : wisuda, info } \\
\text { kepegawaian, } \\
\text { pengumuman, } \\
\text { penyampaian } \\
\text { informasi akademik, } \\
\text { kemahasiswaan, } \\
\text { perpustakaan, } \\
\text { kepegawaian, hingga } \\
\text { informasi arisan } \\
\text { darma wanita UIN } \\
\text { Suska Riau. }\end{array}$ \\
\hline
\end{tabular}

\begin{tabular}{|c|c|c|}
\hline 10 & $\begin{array}{l}\text { Sistem } \\
\text { Kinerja Staf }\end{array}$ & $\begin{array}{l}\text { Digunakan sebagai } \\
\text { media pencatatan } \\
\text { catatan kerja rutin } \\
\text { staf, track record } \\
\text { pekerjaan harian, } \\
\text { laporan rutinitas } \\
\text { pekerjaan pegawai } \\
\text { harian. }\end{array}$ \\
\hline 11 & $\begin{array}{l}\text { Sistem } \\
\text { Informasi } \\
\text { Kemahasisw } \\
\text { aan dan } \\
\text { Akademik } \\
\text { http://simak. } \\
\text { uin- } \\
\text { suska.ac.id }\end{array}$ & $\begin{array}{l}\text { Digunakan sebagai } \\
\text { media untuk sistem } \\
\text { untuk mengelola } \\
\text { akademik dan } \\
\text { kemahasiswaan. } \\
\text { Seperti transkip nilai, } \\
\text { kartu rencana studi } \\
\text { mahasiswa, jadwal } \\
\text { kuliah, dan semua } \\
\text { yang berkaitan } \\
\text { dengan akademik dan } \\
\text { kemahasiswaan. }\end{array}$ \\
\hline
\end{tabular}

\section{Arsitektur Jaringan Fiber Optic UIN Suska Riau}

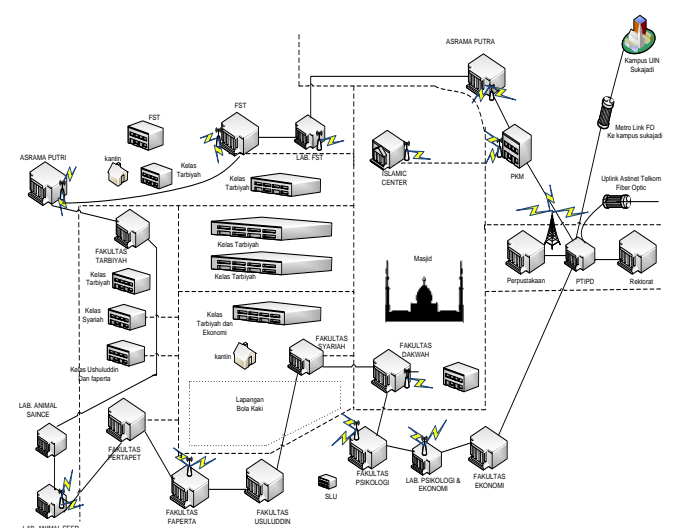

Gambar. 2 Arsitektur Jaringan Fiber Optic UIN Suska

\section{Analisis Lingkungan Internal Organisasi}

Analisis terhadap lingkungan internal bisnis organisasi merupakan analisis terhadap faktor - faktor internal yang mempengaruhi kegiatan bisnis organisasi, baik yang berupa kekuatan internal yang dimiliki organisasi yang harus digali potensinya sehingga peluang yang ada dapat dimanfaatkan sebaik mungkin, atau pun berupa kelemahan yang harus diperbaiki oleh organisasi supaya tidak menjadi 
ancaman bagi organisasi dikemudian hari. Analisis yang dilakukan mencakup analisis SWOT (Strength, Weakness, Oppurtunities, Threats)(Rangkuti, 2013).

Analisis SWOT dilakukan dengan menggunakan faktor internal organisasi berupa kekuatan dan kelemahan organisasi dan faktor eksternal organisasi, berupa peluang dan ancaman pada organisasi. Analisis terhadap aspek tersebut dilakukan berdasarkan atas: Anatomi Kuadran, Pembobotan dan Rating. Berikut ini merupakan indikator-indikator SWOT dari Pusat Teknologi Informasi dan Pangkalan Data (PTIPD) UIN Suska :

1. Kekuatan (Strenght)

a. Mempunyai infrastruktur jaringan yang sudah memenuhi kebutuhan standar teknologi informasi

b. Memliki gedung yang cukup luas dengan beberapa fasilitas didalamnya, seperti ruang server, laboratorium, dan warung komputer.

c. Memiliki sumber dana yang memadai untuk mendukung kegiatan pengembangan teknologi informasi.

d. PTIPD merupakan pusat pangkalan data yang mengelola teknologi informasi di lingkungan UIN Suska Riau

2. Kelemahan (Weakness)

a. PTIPD masih menggunakan RIPTI yang lama yaitu tahun 2007, sehingga tidak update dengan perkembangan teknologi.

b. Jumlah fasilitas TI yang tidak sesuai dengan jumlah pemakainya yaitu dosen, mahasiswa dan pegawai.

c. Belum tersedianya backup server secara fisik.

d. Kualitas SDM yang belum memadai.

\section{Peluang (Opportunities)}

a. Pertumbuhan internet yang sangat pesat dapat dimanfaatkan sebagai media pendekatan ke pemakai dengan lebih efektif dan efisien.

b. Lokasi yang strategis untuk mendukung kerjasama dengan negara tetangga, seperti Singapura dan Malaysia

c. Meningkatnya jumlah mahasiswa, sehingga meningkat pula jumlah pengguna teknlogi informasi

d. Menjalin kerjasama yang baik terhadap stakeholder untuk perkembangan teknologi informasi.

e. Semakin murahnya nilai teknologi informasi dan komunikasi.

f. Meningkatnya taraf hidup pemakai yang mampu memiliki laptop atau komputer pribadi di rumah dan telepon seluler.

\section{Ancaman (Threats)}

a. Pertumbuhan teknologi informasi yang sangat cepat yang membuat teknologi saat ini cepat usang dan harus cepat diganti dengan yang baru sehingga membutuhkan dana yang besar.

b. Kurangnya penghargaan (reward) bagi SDM IT yang memiliki skill/keahlian khusus, sehingga dapat mempengaruhi hasil kinerja SDM.

c. Adanya universitas lain yang memiliki teknologi yang serupa dengan teknologi yang dimiliki sehingga akan terjadi perbandingan dan persaingan, seperti UR dan UIR.

d. Tingkat keamanan di lingkungan UIN yang kurang kondusif. 


\section{Skala Prioritas Berdasarkan SWOT}

Tabel. 2 Skala Prioritas berdasarkan SWOT

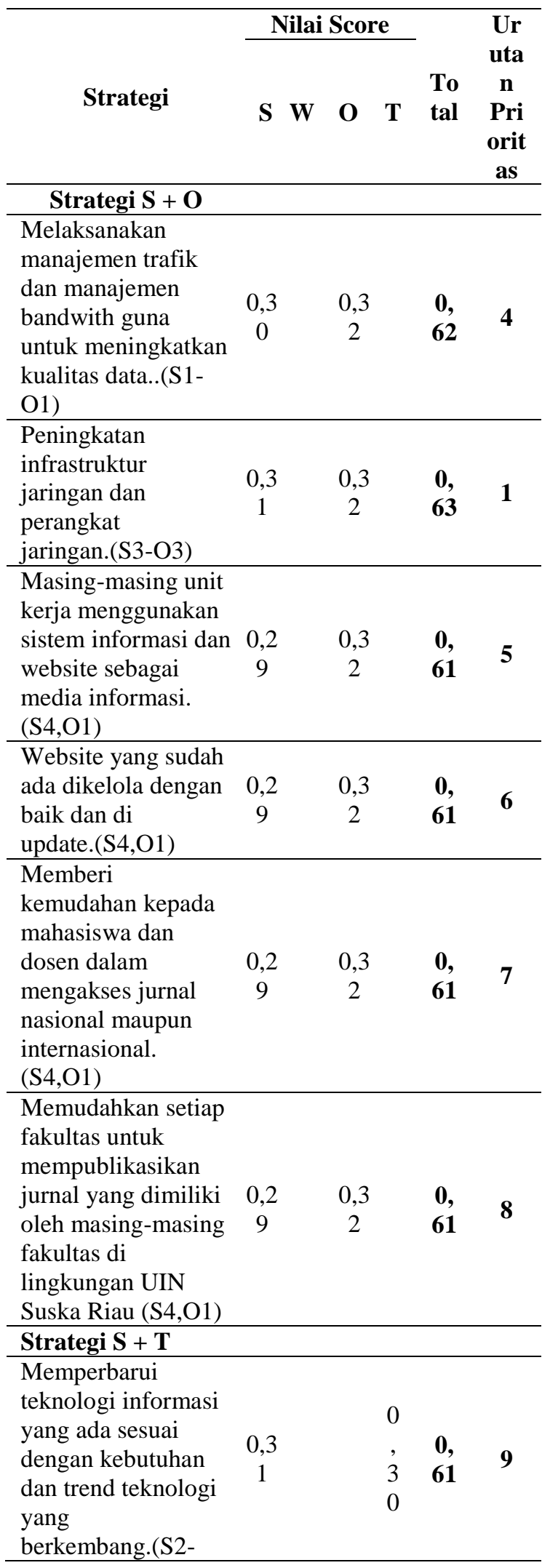

\begin{tabular}{|c|c|c|c|c|}
\hline T3) & & & & \\
\hline $\begin{array}{l}\text { Mengalokasikan } \\
\text { dana untuk sistem } \\
\text { keamanan di } \\
\text { lingkungan UIN } \\
\text { Suska Riau terutama } \\
\text { di PTIPD, seperti } \\
\text { memasang } \\
\text { perangkat CCTV. } \\
\text { (S3-T4) }\end{array}$ & $\begin{array}{c}0,3 \\
1\end{array}$ & $\begin{array}{c}0,2 \\
1\end{array}$ & $\begin{array}{c}\text { 0, } \\
\mathbf{5 2}\end{array}$ & 11 \\
\hline Strategi W + O & & & & \\
\hline $\begin{array}{l}\text { Melakukan } \\
\text { kerjasama dengan } \\
\text { berbagai pihak } \\
\text { untuk meningkatkan } \\
\text { pengembangan IT, } \\
\text { yaitu dengan } \\
\text { menyusun Rencana } \\
\text { Induk } \\
\text { Pengembangan } \\
\text { Teknologi Informasi } \\
\text { (RIPTI) yang baru } \\
\text { dan dapat } \\
\text { diperbaharui secara } \\
\text { berkala.(W1-O4) }\end{array}$ & 0,31 & $\begin{array}{c}0,3 \\
2\end{array}$ & $\begin{array}{l}\mathbf{0}, \\
\mathbf{6 3}\end{array}$ & 2 \\
\hline $\begin{array}{l}\text { Tersedianya } \\
\text { database server yang } \\
\text { sesuai dengan } \\
\text { kebutuhan UIN } \\
\text { Suska Riau. } \\
(\text { W2,O5) }\end{array}$ & 0,31 & $\begin{array}{c}0,3 \\
0\end{array}$ & $\begin{array}{l}\mathbf{0}, \\
\mathbf{6 1}\end{array}$ & 10 \\
\hline $\begin{array}{l}\text { Meningkatkan } \\
\text { jumlah dan kualitas } \\
\text { sumber daya TI agar } \\
\text { sesuai dengan } \\
\text { jumlah pengguna } \\
\text { yang ada di } \\
\text { lingkungan UIN } \\
\text { Suska Riau (W2- } \\
\text { O3) }\end{array}$ & 0,31 & $\begin{array}{c}0,3 \\
2\end{array}$ & $\begin{array}{l}\mathbf{0}, \\
\mathbf{6 3}\end{array}$ & 3 \\
\hline $\begin{array}{l}\text { Menyediakan } \\
\text { backup server secara } \\
\text { fisik untuk } \\
\text { mendukung } \\
\text { pengembanngan IT } \\
\text { kedepannya.(W3- } \\
\text { O5) }\end{array}$ & 0,19 & $\begin{array}{c}0,3 \\
0\end{array}$ & $\begin{array}{c}\mathbf{0} \\
\mathbf{4 9}\end{array}$ & 13 \\
\hline Strategi W + T & & & & \\
\hline $\begin{array}{l}\text { Meningkatkan } \\
\text { jumlah fasilitas TI } \\
\text { agar sesuai dengan } \\
\text { jumlah pengguna } \\
\text { (W2-T1) }\end{array}$ & 0,31 & 0,21 & $\begin{array}{c}\mathbf{0}, \\
52\end{array}$ & 12 \\
\hline $\begin{array}{l}\text { Terciptanya sumber } \\
\text { daya manusia yang } \\
\text { ahli dibidang } \\
\text { teknologi informasi }\end{array}$ & 0,20 & 0,21 & $\begin{array}{l}\mathbf{0}, \\
41\end{array}$ & 14 \\
\hline
\end{tabular}




\begin{tabular}{lllll}
\hline (W4-T1) & & & & \\
\hline Meningkatkan & & & & \\
kualitas pegawai & & & & \\
PTIPD di bidang & & & & \\
teknologi informasi & 0,20 & 0,19 & $\mathbf{0 9}$ & $\mathbf{1 5}$ \\
dengan memberikan & & & & \\
pelatihan untuk & & & & \\
sertifikasi & & & & \\
profesi.(W4,T2) & & & & \\
\hline
\end{tabular}

\section{Analisis Internal Bisnis PTIPD UIN Suska Riau}

Untuk menganalisa kondisi internal bisnis PTIPD UIN Suska Riau akan diuraikan dari tujuan dan sasaran organisasi beserta masalah yang dihadapi yang nantinya digunakan untuk menentukan langkah-langkah yang tepat untuk mengatasinya. Adapun tujuan dan sasaran strategis berdasarkan SWOT yang ingin dicapai oleh Pusat Teknologi Informasi dan Pangkalan Data (PTIPD) UIN Suska Riau adalah sebagai berikut :

Tabel. 3 Tujuan dan Sasaran Strategis

\begin{tabular}{|c|c|}
\hline Tujuan & Sasaran Strategis \\
\hline $\begin{array}{l}\text { 1. Meningkatkan } \\
\text { kualitas layanan } \\
\text { internet untuk } \\
\text { semua civitas } \\
\text { akademika UIN } \\
\text { Suska. }\end{array}$ & 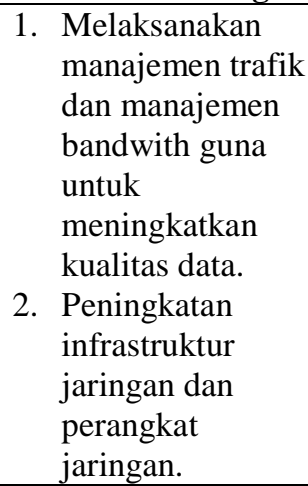 \\
\hline $\begin{array}{l}\text { 2. Menjadi bank data } \\
\text { untuk seluruh } \\
\text { aplikasi dan sistem } \\
\text { informasi yang ada } \\
\text { di UIN Suska. }\end{array}$ & 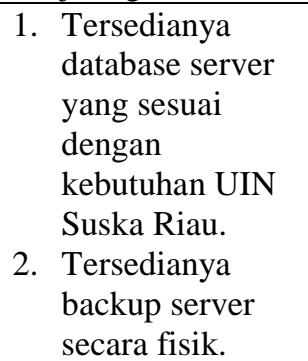 \\
\hline $\begin{array}{l}\text { 3. } \\
\text { Mengembangkan } \\
\text { sistem informasi } \\
\text { dan website untuk } \\
\text { membantu kegiatan } \\
\text { manajemen di }\end{array}$ & $\begin{array}{l}\text { 1. Masing-masing } \\
\text { unit kerja } \\
\text { menggunakan } \\
\text { sistem informasi } \\
\text { dan website }\end{array}$ \\
\hline
\end{tabular}

\begin{tabular}{|c|c|c|}
\hline & $\begin{array}{l}\text { lingkungan UIN } \\
\text { Suska. }\end{array}$ & $\begin{array}{l}\text { sebagai media } \\
\text { informasi. } \\
\text { 2. Website yang } \\
\text { sudah ada } \\
\text { dikelola dengan } \\
\text { baik dan di } \\
\text { update. }\end{array}$ \\
\hline 4. & $\begin{array}{l}\text { Meningkatkan } \\
\text { kualitas sumber } \\
\text { daya manusia } \\
\text { dengan pelatihan } \\
\text { dengan standar } \\
\text { nasional dan } \\
\text { internasional untuk } \\
\text { mahasiswa dan } \\
\text { dosen. }\end{array}$ & $\begin{array}{l}\text { 1. Terciptanya } \\
\text { sumber daya } \\
\text { manusia yang } \\
\text { ahli dibidang } \\
\text { teknologi } \\
\text { informasi. } \\
\text { 2. Meningkatkan } \\
\text { kualitas pegawai } \\
\text { PTIPD di bidang } \\
\text { teknologi } \\
\text { informasi dengan } \\
\text { memberikan } \\
\text { pelatihan untuk } \\
\text { sertifikasi profesi. }\end{array}$ \\
\hline 5. & $\begin{array}{l}\text { Menyediakan } \\
\text { layanan e-jurnal } \\
\text { untuk } \\
\text { mempermudah } \\
\text { akses jurnal } \\
\text { nasional maupun } \\
\text { jurnal berlangganan }\end{array}$ & $\begin{array}{l}\text { 1. } \text { Memberi } \\
\text { kemudahan } \\
\text { kepada } \\
\text { mahasiswa dan } \\
\text { dosen dalam } \\
\text { mengakses jurnal } \\
\text { nasional maupun } \\
\text { internasional. } \\
\text { 2. Memudahkan } \\
\text { setiap fakultas } \\
\text { untuk } \\
\text { mempublikasikan } \\
\text { jurnal yang } \\
\text { dimiliki oleh } \\
\text { masing-masing } \\
\text { fakultas di } \\
\text { lingkungan UIN } \\
\text { Suska Riau. }\end{array}$ \\
\hline
\end{tabular}

Berdasarkan dari tabel diatas maka akan dijelaskan permasalahanpermasalahan yang dihadapi dan solusinya untuk pencapaian sasaransasaran strategis Pusat Teknologi Informasi dan pangkalan Data (PTIPD) UIN Suska Riau adalah sebagai berikut :

Tabel. 4 Sasaran, Permasalahan dan Solusi

\begin{tabular}{lll}
\hline \multicolumn{1}{c}{ Sasaran } & \multicolumn{1}{c}{ Permasalahan } & \multicolumn{1}{c}{ Solusi } \\
\hline 1. Melaksana & Selama ini & Pengguna \\
kan & aplikasi MRTG & an aplikasi \\
manajeme & tidak pernah & untuk \\
\hline
\end{tabular}




\begin{tabular}{|c|c|c|c|}
\hline & $\begin{array}{l}\mathrm{n} \text { trafik } \\
\text { dan } \\
\text { manajeme } \\
\mathrm{n} \\
\text { bandwith } \\
\text { guna } \\
\text { untuk } \\
\text { meningkat } \\
\text { kan } \\
\text { kualitas } \\
\text { data. }\end{array}$ & dipantau. & $\begin{array}{l}\text { pengelolaa } \\
\mathrm{n} \\
\text { bandwith } \\
\text { seperti } \\
\text { sistem } \\
\text { informasi } \\
\text { monitorin } \\
\text { g trafik } \\
\text { data. }\end{array}$ \\
\hline 2. & $\begin{array}{l}\text { Peningkat } \\
\text { an } \\
\text { infrastrukt } \\
\text { ur jaringan } \\
\text { dan } \\
\text { perangkat } \\
\text { jaringan. }\end{array}$ & $\begin{array}{l}\text { Masih sulitnya } \\
\text { mendapatkan } \\
\text { jaringan hotspot } \\
\text { di beberapa } \\
\text { tempat di } \\
\text { lingkungan UIN } \\
\text { Suska Riau. }\end{array}$ & $\begin{array}{l}\text { Menyedia } \\
\text { kan } \\
\text { hotspot di } \\
\text { seluruh } \\
\text { gedung di } \\
\text { lingkunga } \\
\text { n UIN } \\
\text { Suska } \\
\text { Riau }\end{array}$ \\
\hline 3. & $\begin{array}{l}\text { Tersedian } \\
\text { ya } \\
\text { database } \\
\text { server } \\
\text { yang } \\
\text { sesuai } \\
\text { dengan } \\
\text { kebutuhan } \\
\text { UIN Suska } \\
\text { Riau. }\end{array}$ & $\begin{array}{l}\text { Kapasitas server } \\
\text { yang ada belum } \\
\text { mencukupi. }\end{array}$ & $\begin{array}{l}\text { Update } \\
\text { server. }\end{array}$ \\
\hline 3. & $\begin{array}{l}\text { Tersedian } \\
\text { ya backup } \\
\text { server } \\
\text { secara } \\
\text { fisik. }\end{array}$ & $\begin{array}{l}\text { Saat ini belum } \\
\text { memiliki backup } \\
\text { server secara } \\
\text { fisik sehingga } \\
\text { apabila terjadi } \\
\text { kerusakan } \\
\text { server, maka } \\
\text { resiko } \\
\text { kehilangan data } \\
\text { akan lebih besar. }\end{array}$ & $\begin{array}{l}\text { Pengadaan } \\
\text { backup } \\
\text { server } \\
\text { secara } \\
\text { fisik. }\end{array}$ \\
\hline 4. & $\begin{array}{l}\text { Masing- } \\
\text { masing } \\
\text { unit kerja } \\
\text { mengguna } \\
\text { kan sistem } \\
\text { informasi } \\
\text { dan } \\
\text { website } \\
\text { sebagai } \\
\text { media } \\
\text { informasi. }\end{array}$ & $\begin{array}{l}\text { Belum semua } \\
\text { unit kerja di } \\
\text { lingkungan UIN } \\
\text { Suska } \\
\text { menggunakan } \\
\text { sistem informasi } \\
\text { dan memiliki } \\
\text { website sendiri. }\end{array}$ & $\begin{array}{l}\text { Meningkat } \\
\text { kan } \\
\text { jumlah } \\
\text { aplikasi } \\
\text { yang } \\
\text { dikemban } \\
\text { gkan oleh } \\
\text { PTIPD } \\
\text { untuk } \\
\text { masing- } \\
\text { masing } \\
\text { unit kerja. }\end{array}$ \\
\hline 5. & $\begin{array}{l}\text { Website } \\
\text { yang } \\
\text { sudah ada } \\
\text { dikelola } \\
\text { dengan } \\
\text { baik dan }\end{array}$ & $\begin{array}{l}\text { Tidak semua } \\
\text { website yang } \\
\text { ada saat ini di } \\
\text { update. }\end{array}$ & $\begin{array}{l}\text { Membuat } \\
\text { aplikasi } \\
\text { warning } \\
\text { update } \\
\text { untuk } \\
\text { masing- }\end{array}$ \\
\hline
\end{tabular}

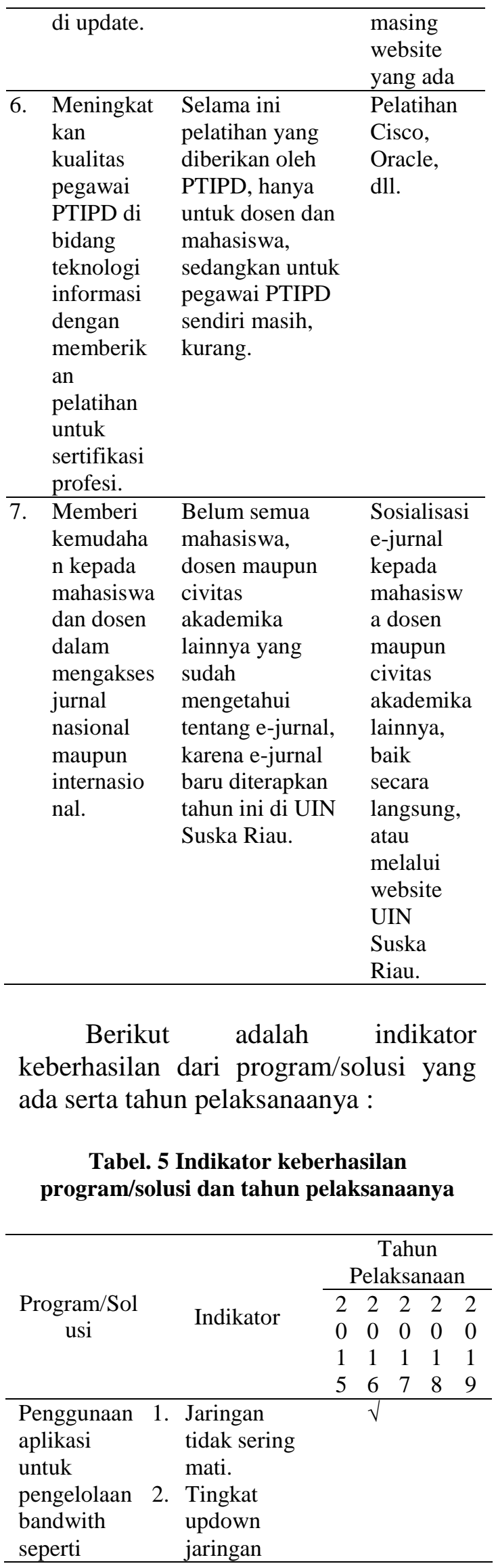




\begin{tabular}{|c|c|c|c|c|}
\hline $\begin{array}{l}\text { sistem } \\
\text { informasi } \\
\text { monitoring } \\
\text { trafik data. }\end{array}$ & & $\begin{array}{l}\text { dalam satu } \\
\text { minggu } \\
\text { minimal } 5 \mathrm{x} \\
5 \text { jam kerja } \\
(25 \text { jam })\end{array}$ & & \\
\hline $\begin{array}{l}\text { Menyediaka } \\
\mathrm{n} \text { hotspot di } \\
\text { seluruh } \\
\text { gedung di } \\
\text { lingkungan } \\
\text { UIN Suska } \\
\text { Riau }\end{array}$ & $\begin{array}{l}1 . \\
2 .\end{array}$ & $\begin{array}{l}\text { Seluruh } \\
\text { gedung telah } \\
\text { terhubung } \\
\text { dengan } \\
\text { jaringan FO. } \\
\text { Tersedianya } \\
\text { perangkat } \\
\text { jaringan } \\
\text { hotspot } \\
\text { seperti acces } \\
\text { point, dll di } \\
\text { setiap } \\
\text { gedung. }\end{array}$ & $\sqrt{ }$ & \\
\hline $\begin{array}{l}\text { Update } \\
\text { server. }\end{array}$ & $\begin{array}{l}1 . \\
2 . \\
2 . \\
3 .\end{array}$ & $\begin{array}{l}\text { Memiliki } \\
\text { sumber dana } \\
\text { yang cukup } \\
\text { Tersedianya } \\
\text { tempat } \\
\text { ruangan } \\
\text { penyimpana } \\
\text { n server. } \\
\text { Memiliki } \\
\text { keamanan } \\
\text { cctv pada } \\
\text { rungan } \\
\text { server }\end{array}$ & & $\sqrt{ }$ \\
\hline $\begin{array}{l}\text { Pengadaan } \\
\text { backup } \\
\text { server } \\
\text { secara fisik. }\end{array}$ & 1. & $\begin{array}{l}\text { Memiliki } \\
\text { sumber dana } \\
\text { yang cukup } \\
\text { Tersedianya } \\
\text { tempat } \\
\text { ruangan } \\
\text { penyimpana } \\
\text { n server. } \\
\text { Memiliki } \\
\text { keamanan } \\
\text { cctv pada } \\
\text { rungan } \\
\text { server }\end{array}$ & & $\sqrt{ }$ \\
\hline $\begin{array}{l}\text { Meningkatk } \\
\text { an jumlah } \\
\text { aplikasi } \\
\text { yang } \\
\text { dikembangk } \\
\text { an oleh } \\
\text { PTIPD } \\
\text { untuk } \\
\text { masing- } \\
\text { masing unit } \\
\text { kerja. }\end{array}$ & $\begin{array}{l}2 . \\
3 .\end{array}$ & $\begin{array}{l}\text { Tersedianya } \\
\text { server yang } \\
\text { sesuai } \\
\text { dengan } \\
\text { kebutuhan } \\
\text { aplikasi } \\
\text { yang akan } \\
\text { dikembangk } \\
\text { an } \\
\text { Memiliki } \\
\text { sumber dana } \\
\text { yang cukup. } \\
\text { Tersedianya } \\
\text { jaringan }\end{array}$ & & $\sqrt{ }$ \\
\hline
\end{tabular}

\begin{tabular}{|c|c|c|c|c|}
\hline & & $\begin{array}{l}\text { internet } \\
\text { yang sesuai } \\
\text { dengan } \\
\text { kebutuhan } \\
\text { aplikasi } \\
\text { yang akan } \\
\text { dikembangk } \\
\text { an } \\
\text { Aplikasi } \\
\text { yang akan } \\
\text { dibangun } \\
\text { harus } \\
\text { terintegrasi } \\
\text { dengan } \\
\text { aplikasi } \\
\text { yang sudah } \\
\text { ada. }\end{array}$ & & \\
\hline $\begin{array}{l}\text { Membuat } \\
\text { aplikasi } \\
\text { warning } \\
\text { update untuk } \\
\text { masing- } \\
\text { masing } \\
\text { website } \\
\text { yang ada }\end{array}$ & $\begin{array}{l}1 . \\
2 .\end{array}$ & $\begin{array}{l}\text { Masing- } \\
\text { masing unit } \\
\text { kerja telah } \\
\text { memiliki } \\
\text { website. } \\
\text { Jaringan } \\
\text { tidak sering } \\
\text { mati. }\end{array}$ & $\sqrt{ }$ & \\
\hline $\begin{array}{l}\text { Pelatihan } \\
\text { Cisco, } \\
\text { Oracle, dll. }\end{array}$ & 1. & $\begin{array}{l}\text { Tersedianya } \\
\text { dana untuk } \\
\text { pelatihan. } \\
\text { Terdapat } \\
\text { SDM yang } \\
\text { memiliki } \\
\text { kompetensi } \\
\text { dasar } \\
\text { dibidang IT. }\end{array}$ & & $\sqrt{ }$ \\
\hline $\begin{array}{l}\text { Sosialisasi } \\
\text { e-jurnal } \\
\text { kepada } \\
\text { mahasiswa, } \\
\text { dosen } \\
\text { maupun } \\
\text { civitas } \\
\text { akademika } \\
\text { lainnya, baik } \\
\text { secara } \\
\text { langsung, } \\
\text { atau melalui } \\
\text { website UIN } \\
\text { Suska Riau. }\end{array}$ & $\begin{array}{l}1 . \\
2 .\end{array}$ & $\begin{array}{l}\text { Website uin } \\
\text { harus selalu } \\
\text { update } \\
\text { informasi } \\
\text { Terintegrasi } \\
\text { nya e-jurnal } \\
\text { dengan } \\
\text { website uin } \\
\text { suska. }\end{array}$ & $\sqrt{ }$ & \\
\hline
\end{tabular}

Analisis Internal SI/TI PTIPD UIN Suska Riau

Pusat Teknologi Informasi Dan

Pangkalan Data (PTIPD) merupakan organisasi yang mengelola seluruh jaringan komputer yang ada di lingkungan UIN Suska Riau. Jaringan 
yang ada saat ini menggunakan kabel fiber optic $(F O)$ dengan topologi ring. Saat ini terdapat 24 titik switch untuk jaringan utama (FO) dan dari setiap titik memiliki jaringan LAN sendiri didalamnya. Untuk kekuatan bandwidth UIN Suska Riau saat ini sebesar 200 Mbps. Dengan kekuatan bandwidth sebesar itu, menurut Kepala Pusat Teknologi Informasi Dan Pangkalan Data (PTIPD) sudah dapat mendukung kinerja saat ini, akan tetapi karena pengguna yang semakin meningkat, maka perlu untuk dinaikkan lagi kekuatan bandwidthnya.

Pusat Teknologi Informasi Dan Pangkalan Data (PTIPD) memiliki beberapa sistem informasi dan software aplikasi yaitu Aplikasi billing internet yang digunakan untuk mengelola data pengguna internet di lingkungan kampus meliputi hak akses internet bagi dosen, pegawai dan mahasiswa. Elearning yang digunakan untuk pembelajaran jarak jauh. Sistem ini menggunakan aplikasi elektronik untuk mendukung belajar mengajar dengan media internet, jaringan computer, maupun computer standalone. Staffsite yang digunakan sebagai media berbagi informasi antar staf PTIPD UIN Suska Riau.

Web personal dosen yang digunakan sebagai media informasi antar dosen di UIN Suska Riau. Web ini dikelola oleh PTIPD sebagai bentuk tanggung jawab pencapaian visi PTIPD. Blog mahasiswa yang digunakan sebagai media bertukar informasi antar mahasiswa UIN Suska Riau. Sistem pendaftaran online yang digunakan sebagai tempat untuk melakukan pendaftaran mahasiswa baru melalui jalur mandiri (UMJM) secara online. Sistem informasi kepegawaiaanyang berguna untuk mengelola data kepegawaiaan UIN Suska Riau, antara lain data pegawai, kepangkatan dan jabatan, dimana saat ini masih berbasis desktop.

Sistem informasi UIN Suska Riau yang berguna sebagai media penyimpanan informasi mengenai hal yang berkaitan dengan kampus UIN Suska. SMS Gateway yang digunakan sebagai media untuk penyampaian informasi missal, contoh : wisuda, info kepegawaian, pengumuman, penyampaian informasi akademik, kemahasiswaan, perpustakaan, kepegawaian, hingga informasi arisan darma wanita UIN Suska Riau.Sistem kinerja stafyang digunakan sebagai media pencatatan catatan kerja rutin staf, track record pekerjaan harian, laporan rutinitas pekerjaan pegawai harian, sistem informasi kemahasiswaan dan akademik (SIMAK) yang digunakan sebagai media untuk sistem untuk mengelola akademik dan kemahasiswaan.

Seperti transkip nilai, kartu rencana studi mahasiswa, jadwal kuliah, dan semua yang berkaitan dengan akademik dan kemahasiswaan. Wisuda Online yang digunakan untuk informasi dan pendaftaran wisuda secara online. Sistem Registrasi (SIREG) yang digunakan utuk meregistrasi mahasiswa UIN Suska Riau.

Namun semua sistem informasi yang ada saat ini belum terintegrasi antara satu dengan yang lainnya. Sehingga untuk pemeliharaan sistem informasi dan software aplikasi saat ini belum semuanya dapat terkontrol oleh Pusat Teknologi Informasi Dan Pangkalan Data (PTIPD). Hal ini disebabkan karena ada sebagian sistem informasi yang dikelola oleh proses bisnis tertentu, seperti bagian akademik yang mengelola SIMAK sendiri.

Salah satu tujuan dari PTIPD UIN Suska Riau adalah mengembangkan sistem informasi dan website untuk membantu kegiatan manajemen di 
lingkungan UIN Suska Riau. Untuk tercapainya tujuan tersebut diperlukan proses-proses atau kegiatan yang berkaitan dengan pengembangan sistem aplikasi yang sesuai dengan kebutuhan di PTIPD maupun unit kerja lain di lingkungan UIN Suska Riau.

Berikut adalah tabel kebutuhan sistem informasi/aplikasi pada beberapa unit kerja di lingkungan UIN Suska Riau:

Tabel 6. Kebutuhan system informasi/ aplikasi

\begin{tabular}{|c|c|c|c|}
\hline $\begin{array}{c}\text { Unit } \\
\text { Kerja }\end{array}$ & $\begin{array}{c}\text { Sistem } \\
\text { Aplikasi } \\
\text { Yang } \\
\text { Digunaka } \\
\text { n Saat Ini }\end{array}$ & $\begin{array}{l}\text { Kendala } \\
\text { Sistem } \\
\text { Yang } \\
\text { Dihadapi }\end{array}$ & $\begin{array}{c}\text { Sistem } \\
\text { Aplikasi } \\
\text { Yang } \\
\text { Dibutuhk } \\
\text { an }\end{array}$ \\
\hline $\begin{array}{l}\text { Kemah } \\
\text { asiswa } \\
\text { an dan } \\
\text { Alumn } \\
\text { i }\end{array}$ & Belum ada & - & $\begin{array}{l}\text { Sistem } \\
\text { Informasi } \\
\text { Beasiswa } \\
\text { dan } \\
\text { Sistem } \\
\text { Informasi } \\
\text { Alumni }\end{array}$ \\
\hline $\begin{array}{l}\text { Kerjas } \\
\text { ama }\end{array}$ & Belum ada & - & Website \\
\hline Umum & Belum ada & - & $\begin{array}{l}\text { Sistem } \\
\text { informasi } \\
\text { surat- } \\
\text { menyurat }\end{array}$ \\
\hline $\begin{array}{l}\text { TV } \\
\text { Madan } \\
\text { i }\end{array}$ & $\begin{array}{l}\text { Sistem } \\
\text { informasi } \\
\text { redaksi } \\
\text { berupa } \\
\text { website } \\
\text { (www.suka } \\
\text { madani.tv) }\end{array}$ & $\begin{array}{l}\text { Untuk } \\
\text { sistem } \\
\text { tidak ada } \\
\text { kendala, } \\
\text { hanya saja } \\
\text { untuk } \\
\text { koneksi } \\
\text { jaringanny } \\
\text { a TV } \\
\text { Madani } \\
\text { tidak } \\
\text { mengguna } \\
\text { kan } \\
\text { jaringan } \\
\text { yang } \\
\text { disediakan } \\
\text { oleh UIN, } \\
\text { karena } \\
\text { kapasitas } \\
\text { untuk } \\
\text { menguplo } \\
\text { ad konten }\end{array}$ & $\begin{array}{l}\text { TV } \\
\text { madani } \\
\text { membutuh } \\
\text { kan } \\
\text { koneksi } \\
\text { jaringan } \\
\text { yang } \\
\text { sesuai } \\
\text { dengan } \\
\text { kapasitas } \\
\text { TV } \\
\text { madani. }\end{array}$ \\
\hline
\end{tabular}

\begin{tabular}{|c|c|c|c|}
\hline & & $\begin{array}{l}\text { TV } \\
\text { madani } \\
\text { membutuh } \\
\text { kan 1Gbps } \\
\text { sedangkan } \\
\text { di UIN } \\
\text { yang } \\
\text { tersedia } \\
\text { sebesar } \\
45 \mathrm{Mbps} .\end{array}$ & \\
\hline $\begin{array}{l}\text { Kepeg } \\
\text { awaian }\end{array}$ & $\begin{array}{l}\text { Sistem } \\
\text { Informasi } \\
\text { Manajeme } \\
\mathrm{n} \\
\text { Kepegawai } \\
\text { an } \\
\text { (SIMPEG) } \\
\text { berbasis } \\
\text { online }\end{array}$ & $\begin{array}{l}\text { Untuk } \\
\text { sistem } \\
\text { yang ada } \\
\text { saat ini } \\
\text { tidak ada } \\
\text { mengalam } \\
\text { i kendala, } \\
\text { hanya saja } \\
\text { sistem ini } \\
\text { bukan } \\
\text { dikelola } \\
\text { oleh } \\
\text { PTIPD } \\
\text { melainkan } \\
\text { oleh } \\
\text { KEMENA } \\
\text { G Pusat. }\end{array}$ & $\begin{array}{l}\text { Sistem } \\
\text { Informasi } \\
\text { Manajeme } \\
\mathrm{n} \\
\text { Kepegawa } \\
\text { ian } \\
\text { (SIMPEG } \\
\text { ) yang } \\
\text { dikelola } \\
\text { oleh } \\
\text { PTIPD }\end{array}$ \\
\hline $\begin{array}{l}\text { Akade } \\
\text { mik }\end{array}$ & $\begin{array}{l}\text { Sistem } \\
\text { Informasi } \\
\text { Mahasiswa } \\
\text { dan } \\
\text { Akademik } \\
\text { (SIMAK), } \\
\text { Sistem } \\
\text { Informasi } \\
\text { Pendaftara } \\
\text { n Online, } \\
\text { Sistem } \\
\text { Informasi } \\
\text { Registrasi, } \\
\text { Sistem } \\
\text { Informasi } \\
\text { Wisuda } \\
\text { Online }\end{array}$ & $\begin{array}{l}\text { Terdapat } \\
\text { beberapa } \\
\text { kendala } \\
\text { yang tidak } \\
\text { bisa } \\
\text { dijelaskan }\end{array}$ & $\begin{array}{l}\text { Sistem } \\
\text { Informasi } \\
\text { Terintegra } \\
\text { si }\end{array}$ \\
\hline
\end{tabular}

Portofolio Aplikasi saat ini adalah analisis yang digunakan untuk menilai aplikasi yang digunakan PTIPD UIN Suska Riau saat ini, apakah masuk kategori highpotential, key operational atau support, sesuai dengan kontribusi yang diberikan masing-masing aplikasi pada bisnis perusahaan. Berikut adalah portofolio aplikasi pada Pusat 
Teknologi Informasi dan Pangkalan Data UIN Suska Riau :

Tabel 7. Portofolio Aplikasi saat ini

\begin{tabular}{|c|c|}
\hline STRATEGIC & HIG POTENTIAL \\
\hline Sistem Pendaftaran & Staffsite \\
\hline Online & Web Personal Dosen \\
\hline Aplikasi Billing & Blog Mahasiswa \\
\hline Internet & SMS Gateway UIN \\
\hline Sistem Informasi & Suaka \\
\hline Kepegawaian & E-Learning \\
\hline Sistem Informasi UIN & Webmail \\
\hline Suska & \\
\hline Sistem Kinerja Staff & \\
\hline SIMAK & \\
\hline Wisuda Online & \\
\hline SIREG & \\
\hline $\begin{array}{c}\text { KEY } \\
\text { OPERATIONAL }\end{array}$ & SUPPORT \\
\hline
\end{tabular}

\section{Perancangan Strategi TI PTIPD UIN Suska Riau \\ Isu-isu Strategis}

Isu-isu strategis teknologi informasi yang berkembang di Pusat Teknologi Informasi dan Pangkalan Data (PTIPD) UIN Suska Riau saat ini dapat dikelompokkan menjadi beberapa bagian diantaranya bidang pendidikan dan pembelajaran, bidang penelitian dan bidang pengambian masyarakat. Pengelompokan ini berdasarkan misi PTIPD UIN Suska Riau guna mendukung strategi SWOT yang telah ada. Berikut uraian isu-isu strategis teknologi informasi di PTIPD UIN Suska Riau :

1. Bidang Pendidikan dan Pembelajaran

Dalam bidang ini, bagian yang berperan penting untuk pengembangan teknologi informasi adalah bagian akademik, kemahasiswaan dan alumni. Berikut adalah isu-isu yang berkembang saat ini :

a. Diperlukannya penggunaan aplikasi untuk manajemen trafik dan manajemen bandwith dengan membangun Sistem Informasi Monitoring Jaringan guna meningkatkan kualitas data untuk mendukung kinerja sistem informasi lainnya.

b. Peningkatan infrastruktur jaringan dan perangkat jaringan seperti menambah jumlah bandwidth sesuai dengan kebutuhan pengguna dan menyediakan fasilitas jaringan hotspot di seluruh gedung UIN Suska Riau.

c. Lokasi kampus UIN Suska Riau yang terpisah-pisah dan memiliki area kampus yang cukup luas memerlukan prasarana telepon yang memadai. Selama ini, komunikasi telepon masih memanfaatkan provider seperti PT.Telkom. Oleh karena itu, untuk mengoptimalkan pemanfaatan jaringan untuk kedepannya, maka perlu dikembangkan aplikasi VoIP, sehingga akan tersedia fasilitas telepon kampus yang tidak berbayar. Melalui teknologi VoIP ini, komunikasi dapat dilakukan dengan beberapa cara baikmenggunakan telepon analog maupun softphone yang dapat diinstall di masing-masing PC atau laptop. Hal ini nantitentu akan memberikan efisiensi waktu bagi civitas karena mudah dihubungi dan secara langsung akan berdampakpada efisiensi biaya telekomunikasi di kampus.

d. Pada layanan webmail, PTIPD telah menggunakan Google Apps For Education sebagai alat komunikasi dan kolaborasi untuk seluruh civitas akademis, dengan alamat e-mailnya @uinsuka.ac.id untuk dosen/staff dan @ student.uin-suka.ac.id untuk mahasiswa. Untuk strategi kedepannya, hal ini perlu dioptimalkan dengan penggunaan layanan yang ada pada Google Apps For Education seperti 
Google Scholar yang merupakan layanan yang memungkinkan pengguna malakukan pencarian materi-materi pelajaran berupa teks dalam berbagai format publikasi dan Google Drive yaitu layanan untuk menyimpan file di internet pada storage yang disediakan oleh Google yang akan dikombinasikan nantinya dengan e-learning.

e. Sampai saat ini bagian kemahasiswaan dan alumni UIN Suska Riau belum menggunakan sistem informasi atau aplikasi. Sebelumnya sudah ada tawaran dari PTIPD untuk membuat aplikasi alumni, namun sampai saat ini belum ada realisasinya. Di bagian kemahasiswaan dan alumni terdiri dari 2 bagian yaitu bagian kemahasiswaan yang mengurus beasiswa dan bagian alumni yang mengurus data alumni UIN Suska Riau. Pada bagian Kemahasiswaan membutuhkan sistem atau aplikasi beasiswa untuk informasi beasiswa, sedangkan pada bagian alumni membutuhkan aplikasi alumni yang mampu menampilkan semua data alumni. Diharapkan sistem ini juga terintegrasi dengan sistem yang ada pada bagian akademik seperti wisuda online, karena apabila mahasiswa sudah mendaftarkan diri pada sistem wisuda online maka secara otomatis data tersebut masuk ke sistem alumni.

f. Guna mendukung pembelajaran di UIN Suska Riau, maka pada tahun ini PTIPD bersama Perpustakaan UIN Suska Riau telah mengembangkan e-jurnal sebagai tempat untuk mencari referensi yang diperlukan oleh mahasiswa maupun dosen. g. Saat ini sistem informasi yang ada di akademik seperti Sistem Pendaftaran Online Mahasiswa Baru, SIREG, SIMAK, dan Wisuda Online belum dikelola sepenuhnya oleh PTIPD dan juga belum terintegrasi, sehingga strategi untuk kedepannya perlu dibangun Enterprise System Akademik dan Web Portal Akademi. Untuk pengelolaan sistem informasi yang ada untuk kedepannya akan dilakukan oleh PTIPD UIN suska Riau.

2. Bidang Penelitian dan Bidang Pengabdian Masyarakat

Untuk meningkatkan jumlah aplikasi yang dikembangkan oleh PTIPD untuk masing-masing unit kerja, terutama dibidang penelitian dan pengabdian masyarakat maka perlu dikembangkan sistem informasi sebagai berikut :

a. Sistem Informasi Penelitian

b. Sistem Informasi Kompetensi Dosen

c. Sistem Informasi KKN

d. Sistem Informasi Pengabdian Masyarakat

e. Sistem Informasi Penjaminan Mutu

f. Sistem Informasi Penelitian berbasis GIS

g. Web Portal Penelitian dan Pengmas

h. Knowledge Management System

\section{Portofolio Aplikasi Masa Depan}

Portofolio aplikasi masa depan merupakan penjabaran dari aplikasi yang digunakan oleh PTIPD UIN Suska untuk yang akan datang, menghasilkan informasi yang dibutuhkan oleh organisasi guna mendukung kegiatan bisnis organisasi. Selain itu, portofolio aplikasi digunakan sebagai dasar untuk mengidentifikasikan suatu kebutuhan 
organisasi terhadap perangkat teknologi informasi yang akan datang. Maka hasil portofolio aplikasi pada PTIPD UIN Suska Riau dapat dilihat pada tabel dibawah ini :

\section{Tabel 8. Portofolio Aplikasi Masa Depan}

\begin{tabular}{ll}
\hline \multicolumn{1}{c}{ Strategic } & \multicolumn{1}{c}{ Hig Potential } \\
\hline Enterprise System & Web Portal Akademik \\
Akademik & SI Penelitian dan \\
Web Portal Penelitian & Pengmas berbasis \\
\& Pengmas & GIS \\
Knowledge & \\
Management System & \\
\hline SPMB Online & Blog Mahasiswa \\
SIREG & Webmail \\
SIMAK & SMS Gateway UIN \\
Wisuda Online & Suaka \\
SI Alumni & SI Monitoring \\
E-Learning & Jaringan \\
SI Penelitian & Aplikasi VoIP \\
SI Pemetaan & Google Scholar \\
Kompetensi Dosen & Google Drive \\
SI KKN & E-Jurnal \\
SI Pengabdian & Staffsite \\
Masyarakat & Web Personal Dosen \\
SI Pennjaminan Mutu & \\
\hline \multicolumn{1}{c}{ Key Operational } & \multicolumn{1}{c}{ Support } \\
\hline
\end{tabular}

Berdasarkan hasil pemetaan aplikasi sistem informasi di PTIPD UIN Suska Riau yang disajikan dalam gambar di atas, terdapat beberapa aplikasi yang termasuk pada kategori Key Operational, terdapat 11 aplikasi sistem informasi, yaitu SPMB Online, SIREG, SIMAK, Wisuda Online, SI Alumni, E-Learning, SI Penelitian, SI Pemetaan Kompetensi Dosen, SI KKN, SI Pengabdian Masyarakat, SI Pennjaminan Mutu. Kesebelas aplikasi di atas merupakan aplikasi inti (utama) yang sudah seharusnya tersedia di PTIPD UIN Suska Riau. Jika salah satu atau beberapa aplikasi tersebut tidak tersedia,maka proses bisnis PTIPD UIN Suska Riau akan terganggu atau mengalami hambatan.

Sedangkan pada kategori Support yaitu Blog Mahasiswa, Webmail, SMS
Gateway UIN Suaka, SI Monitoring Jaringan, Aplikasi VoIP, Google Scholar, Google Drive, E-Jurnal, Staffsite, Web Personal Dosen. Aplikasi-aplikasi tersebut cukup diperlukan di PTIPD UIN Suska Riau namuntidak terlalu mempengaruhi proses bisnis utama.

Sementara itu terdapat tiga sistem informasi yang termasuk dalam kategori Strategic, yaitu Enterprise System Akademik, Web Portal Penelitian \& Pengmas,Knowledge Management System. Penerapan sistem informasi tersebut akan meningkatkan daya saing di masa mendatang.

Sedangkan pada kelompok aplikasi yang bersifat high potential, yaitu Web Portal Akademik, SI Penelitian dan Pengmas berbasis GIS. Kedua sistem informasi tersebutakan menghasilkan keuntungan yang relevan, baik bagi strategi secara langsung maupun secara tidak langsung memberikan dampak yang cukup signifikan dengan peningkatan kinerja bisnis.

\section{SIMPULAN}

1. Berdasarkan portofolio aplikasi, aplikasi yang diimplementasikan pada PTIPD UIN Suska Riau sebagai perencanaan strategi sistem informasi kedepan adalah :

a. Enterprise system akademik, web portal penelitian \& pengmas, knowledge management system sebagai aplikasi yang mendukung organisasi dengan memberikan keunggulan bersaing di masa mendatang.

b. SPMB Online, SIREG, SIMAK, Wisuda Online, SI Alumni, ELearning, SI Penelitian, SI Pemetaan Kompetensi Dosen, SI KKN, SI Pengabdian Masyarakat, SI Pennjaminan Mutu untuk kesuksesan organisasi. 
c. Web Portal Akademik, SI Penelitian dan Pengmas berbasis GIS yang dicapai untuk menghasilkan keuntungan yang relevan.

d. Blog Mahasiswa, Webmail, SMS Gateway UIN Suaka, SI Monitoring Jaringan, Aplikasi VoIP, Google Scholar, Google Drive, E-Jurnal, Staffsite, Web Personal Dosen cukup diperlukan untuk mendukung pencapaian tujuan PTIPD UIN Suska Riau, namun tidak terlalu mempengaruhi proses bisnis utama.

2. Belum terintegrasi sistem informasi/aplikasi antara bagian satu dengan bagian lainnya, sehingga mengakibatkan tidak efisiennya kinerja antar struktur organisasi. Sistem database yang belum saling terintegrasi.

\section{DAFTAR PUSTAKA}

Febby, F. (2012). Analisis Perencanaan Strategi Sistem Informasi pada Institusi Pendidikan" Studi Kasus pada STAI AL-Azhar Pekanbaru. Skripsi pada UIN Suska Riau, Pekanbaru : tidak diterbitkan

Indra, D., \& Hendri, H. (2008). Perencanaan Strategis Sistem dan Teknologi Informasi pada St. Ignatius Education Center Palembang, Jurnal Ilmiah STMIK GI MDP, 4(3), 9

Laudon, K. C., \& Laudon, J. P. (2007). Sistem Informasi Manajemen, Jakarta: Salemba Empat

Noerlina, N. (2008). Model Perencanaan Strtegi Sistem dan Teknologi Informasi untuk Bidang Distributor. Jurnal Ichsan Gorontalo, 3(2), 1677.

Rangkuti, F. (2013). Sistem Analisis SWOT : Teknik Membedah Kasus Bisnis, Jakarta: PT. Gramedia
Ward, J. \& Peppard, J. (2002). Strategic Planning for Information System, Third Edition, England: John Wiley \& Sons

Widyaningsih, P. (2012). Perencanaan Strategis Sistem Informsi Pada Institusi Pendidikan Tinggi Menggunakan Analisis Critical Success Factors (Studi Kasus : STMIK Duta Bangsa Surakarta), Tesis, Program Studi Magister Sistem Informasi, Program Pascasarjana, Universitas Diponegoro, Semarang 